\title{
Preliminary Identification of Ground-water Nitrate Sources Using Nitrogen and Carbon Stable Isotopes, Kansas
}

\author{
M. A. Townsend, Kansas Geological Survey, 1930 Constant Avenue, Lawrence, KS 66047 \\ S. A. Macko, University of Virginia, Department of Environmental Sciences, Clark Hall, Charlottesville, VA 22903
}

Revised 6/30/08 from 1/29/08 version

\begin{abstract}
Increasing nitrate-N in ground water is a problem in many areas with limited ground-water supplies, such as westcentral Kansas. However, potential sources of nitrate-N are not known. Nitrate-N concentrations in ground water in the Hays study area in Ellis County, west-central Kansas, range from 0.9 to $26 \mathrm{mg} / \mathrm{L}$. The $\delta^{15} \mathrm{~N}$ signatures of the ground waters are more enriched $(+16.8$ to $+28.7 \%$ o $)$ than those of the soils $(+8.4$ to $+13.7 \%)$, strongly suggesting that nitrogen sources are not from mineralized and labile nitrogen present in the unsaturated zone. In this study, nitrate-N values greater than the U.S. EPA drinking water limit of $10 \mathrm{mg} / \mathrm{L}$ occur with $\delta^{15} \mathrm{~N}$ values of greater than $+10 \%$. This relationship between high nitrate- $\mathrm{N}$ concentrations and enriched $\delta^{15} \mathrm{~N}$ values (greater than $+10 \%$ ) in ground water has been observed in other studies in Kansas and is usually related to a human- and/or animal-waste source.

Soil cores collected near municipal wells had mean total nitrogen values of $1.2-15 \mathrm{mg} / \mathrm{kg}$. Increased $\delta^{15} \mathrm{~N}$ with depth in several of the cores suggests that microbial mineralization, denitrification, or volatilization processes caused the enriched $\delta^{15} \mathrm{~N}$ signatures. Decreasing total nitrogen and nitrate- $\mathrm{N}$ values with depth also help support the idea of microbial processes.

Stable carbon isotopes provide supporting evidence that soils are not a major contributor to the observed nitrate-N concentration in the ground water. $\delta^{13} \mathrm{C}$ values of the dissolved organic carbon (DOC) in soils generally were more enriched (-11.6 to $-18.8 \%$ ) while corresponding ground-water $\delta^{13} \mathrm{C}$ values were more depleted (-19.9 to $-22.2 \%$ ), suggesting that the source of the DOC in ground water is not from the soils.
\end{abstract}

\section{Introduction}

Nitrate-nitrogen (nitrate-N) is a common contaminant in drinking- and irrigation-water supplies in the Midwest (Pope et al., 2001; Spalding and Exner, 1993). Many studies have used the ${ }^{15} \mathrm{~N}$ natural abundance method, as well as the ${ }^{18} \mathrm{O}$ on nitrate for determining sources of nitrate-N in ground water (Kendall, 1998; Kreitler, 1975; Fogg et al., 1998). However, little has been done using ${ }^{13} \mathrm{C}$ natural abundance as a complementary tracer for contaminants in ground water. Sources of ${ }^{13} \mathrm{C}$ ultimately involve $\mathrm{C}_{3}$ or $\mathrm{C}_{4}$ plants that have been utilized as food. Total organic carbon (TOC) and dissolved organic carbon (DOC) are common analyses in soils and water. Use of ${ }^{13} \mathrm{C}$ as a tracer, particularly in farmed areas, might assist in verifying sources of contaminants if sufficient background information and observations can be obtained.
In west-central Kansas, nitrate has become an increasing problem in an area with a limited ground-water supply (Townsend et al., 2001; Townsend and Young, 2000; Townsend and Macko, 2004). The City of Hays has occasional elevated nitrate- $\mathrm{N}$ in its municipal water supply. Other studies in Kansas show that nitrate-N from soil water in more permeable soils are a significant contributor to ground-water nitrogen (Townsend et al., 1996; Townsend and Young, 2000). Because of variable land use and soil of alluvial origin in the study area, it was hypothesized that soil water could be a major contributor to the ground-water contamination in the study area. This study used natural-abundance ${ }^{15} \mathrm{~N}$ and ${ }^{13} \mathrm{C}$ stable isotopes to determine potential sources of nitrogen and carbon to the aquifer and to determine if soil nitrogen is a major contributor to the ground-water nitrate-N problem.

\section{Materials and Methods}

\section{Site Description, Geology, and Land Use}

The study area is located in the city of Hays, Ellis County, in west-central Kansas (fig. 1) where agricultural land use is a mixture of irrigated and dry-land farming. Rangeland and feedlots also are present. Average rainfall is approximately $50 \mathrm{~cm} / \mathrm{yr}(20 \mathrm{in} / \mathrm{yr})$ with potential evapotranspiration of approximately $75 \mathrm{~cm} / \mathrm{yr}$ (30 in/yr) (Thornwaite, 1948 and 1952; Sophocleous, 1998).
Five of the six sampled wells are municipal wells located in the Quaternary alluvial terrace deposits of Big Creek on the southern edge of Hays (fig. 1; Neuhauser and Pool, 1988). These municipal wells were selected based on observed increased nitrate-N concentrations over the years. An agricultural-research-farm irrigation well (Irrigation Well) (fig. 1) also was tested to see if any direct input from long-term fertilizer use would be observed in the ground water. Groundwater flow in the study area is towards Big Creek. Sampled 
wells ranged in depth from 13 to $19 \mathrm{~m}$ (42 to $62 \mathrm{ft}$ ) with depth to water ranging from 7 to $8 \mathrm{~m}(23$ to $26 \mathrm{ft})$. Most of the city wells were installed in 1955, and the Irrigation Well was installed in 1967 (DWR and KGS, 2005).

Land use near the sampled wells is shown in table 1 and fig. 1. The farmed areas and parks are currently treated with commercial fertilizer, not manure, as the nitrogen source (City of Hays manager, personal communication, 2002). However, previous fertilizing and land-use practices in the area are not known. The well in the trailer park is not located near any identifiable abandoned septic systems. Sewer lines have been installed in the city for many years (City of Hays manager, personal communication, 2002).

Soil series in the study area consist predominantly of Roxbury silt loam and Detroit silt loam of alluvial origin. Calcium carbonate is present throughout the soil-profile descriptions of both soil series (Appendix A). Field-soil descriptions for the collected cores agree well with the data from the National Resources Conservation Service (NRCS) soils data base (Appendix A; USDA NRCS, 2002).

Silt and clay percentages in these soils (USDA SCS, 1975) suggest a low hydraulic conductivity and possible lengthy travel time from land surface to ground water. However, both the Roxbury silt loam and the Detroit silt loam have a reported hydraulic-conductivity range of $1.5-5 \mathrm{~cm} / \mathrm{hr}$ (1.2-3.9 ft/day; USDA SCS, 1975). The field-soil descriptions (Appendix A) indicate the presence of fine roots and tubular pores to various depths at all coring sites; these pores and root channels may permit macropore flow and may be a reason for the higher than expected hydraulic conductivity.

\section{Field Protocol for Water-well Sampling and Soil-core Collection}

Five city wells and the irrigation well at a university agricultural-research station (fig. 1) were sampled in May 2002, and one of the city wells (C-27) also was sampled in November 2001. The wells were pumped until the specific conductance stabilized for three consecutive readings. For most of the wells, stabilization of specific conductance occurred within 10 minutes of initiation of pumping. Two of the wells, C-27 (with a high nitrate-N concentration) and C-24 (with the lowest nitrate- $\mathrm{N}$ concentration) were not currently being used by the city. These two wells were pumped for

TABLE 1-Land use near City of Hays wells sampled during study.

\begin{tabular}{ll}
\hline \hline Well & \multicolumn{1}{c}{ Land Use } \\
\hline C-27 & $\begin{array}{l}\text { Farmland to west and south. Closed sewage treatment } \\
\text { plant to west of the well and Big Creek (fig. 1). }\end{array}$ \\
C-19 & $\begin{array}{l}\text { Trailer park. } \\
\text { C-24 }\end{array}$ \\
City park near swimming pool. \\
C-28A & $\begin{array}{l}\text { Car dealership. } \\
\text { C-31 }\end{array}$ \\
Irr. well & $\begin{array}{l}\text { Milo in field park. } \\
\text { Creek between the well and abandoned sewage plant. }\end{array}$ \\
&
\end{tabular}

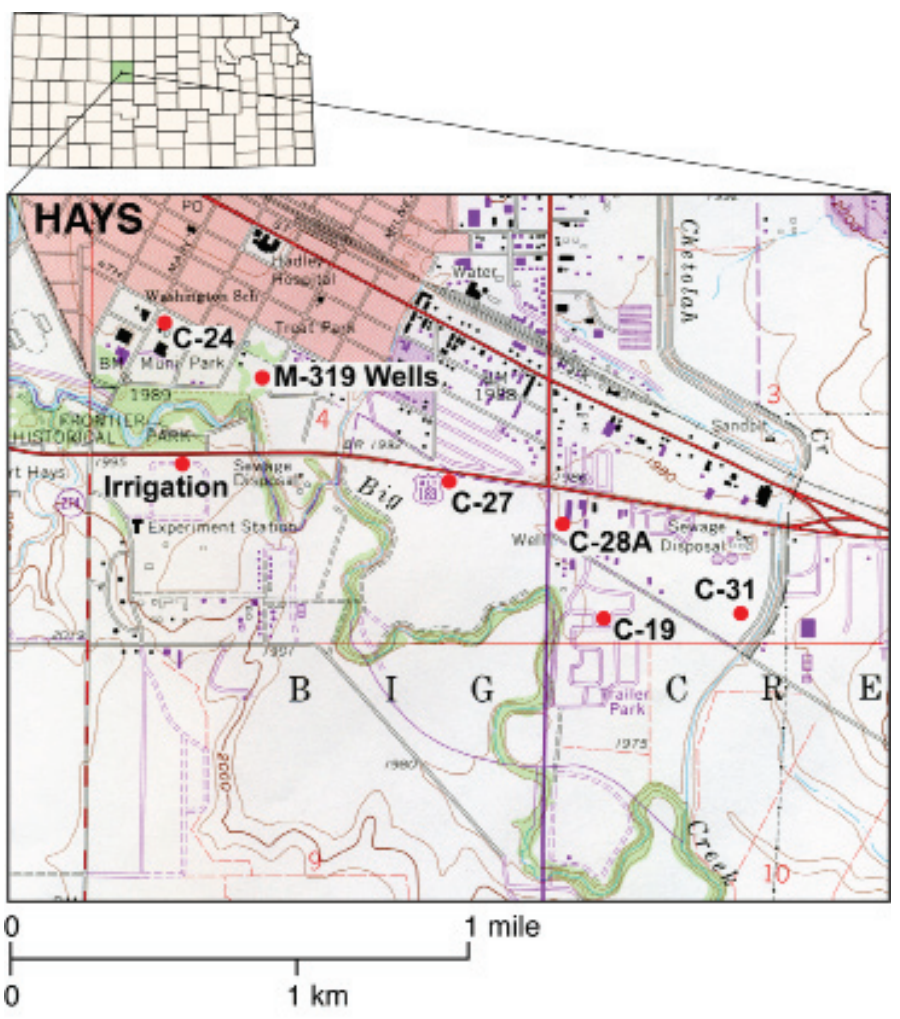

FIGURE 1-Topographic map (USGS, 1983) of study area with sampled wells. The agricultural experiment station, new sewagetreatment plant (north of well C-31), old sewage-treatment plant (west of well C-27), and park and farm areas shown on the map are potential sources of nitrate- $\mathrm{N}$ contamination.

approximately 15-20 minutes until the water ran clear, and then the water was tested for specific conductance and temperature until the readings stabilized.

Soil cores were collected to approximately 5-m depths within $3 \mathrm{~m}$ of four of the city wells (C-27, C-19, C-28A, and $\mathrm{C}-31$ ), in an irrigated field near the Irrigation Well at the agricultural-research station, and near the M-319 cluster of monitoring wells (fig. 1). No core was collected at site C-24 near the swimming pool because the area was cemented in. Cores were taken using a Giddings probe and were described by soil scientists with the northwestern Kansas Natural Resource Conservation Service (NRCS) field office (Appendix A). The collected cores were sub-sampled for chemical analysis (described in next section), stored in plastic bags on ice, and refrigerated upon return to the Kansas Geological Survey (KGS) until delivery to the Kansas State University (KSU) Soil Testing Laboratory in Manhattan.

\section{Water and Soil Chemical Analyses}

Complete inorganic water analyses were performed by the KGS Analytical Services Section. Samples for nitrate- $\mathrm{N}$ analysis were collected in $250-\mathrm{mL}$ bottles and treated with $10 \% \mathrm{HCl}$ acid for preservation. Samples for all other inorganic constituents were collected in acid-rinsed 500-mL polyethylene bottles, with $125-\mathrm{mL}$ bottles used for 
nitrogen-15 analyses. If needed, samples were filtered in the laboratory using a $0.45 \mu$ Micropore $^{\odot}$ filter prior to chemical analysis. Samples were analyzed for major cations (calcium, magnesium, sodium, and potassium) and anions (chloride, bicarbonate, sulfate, nitrate, and fluoride), in addition to $\mathrm{pH}$, specific conductance, temperature, and calculated total dissolved solids using standard methods described by Hathaway et al. (1977). Nitrate was determined using a UV method developed at the KGS (Hathaway, 1990).

The KSU Soil Testing Laboratory performed chemical analyses on soil samples for nitrate-N, ammonium-N, total nitrogen, carbonate, and total organic carbon. Total levels (inorganic and organic) of $\mathrm{C}$ and $\mathrm{N}$ were determined on a dry-weight percent basis using a LECO CN 2000 combustion analyzer (LECO Corp., 1995). Calcium-carbonate percentage was analyzed by pretreatment of a second LECO combustion sample with dilute $(10 \% \mathrm{v} / \mathrm{v}) \mathrm{HCl}$. Carbon dioxide is released from calcium and magnesium carbonates in calcareous soils, leaving only the total organic carbon present (LECO Corp., 2000). Total organic carbon is the $\% \mathrm{C}$ in the acid-treated, carbonate-free sample. Total inorganic carbon is calculated as the difference in the treated and untreated values, and the percentage of carbonates, expressed as $\mathrm{CaCO}_{3}$, is then calculated (KSU, 2006).

For comparison with the observed ground-water values, nitrate-N values from the cores were converted from $\mathrm{mg}$ / $\mathrm{kg}$ to $\mathrm{mg} / \mathrm{L}$ using minimum and maximum oven-dried bulk density and percent-moisture values from the NRCS soil data base for Detroit and Roxbury soils (USDA NRCS, 2006). The bulk density and soil moisture were not measured from the collected cores.

\section{Isotopic Analyses}

Nitrogen-15 and carbon-13 isotope analyses of water and soils were used as source-detection tools to determine sources for the observed nitrate- $\mathrm{N}$ values in the ground water at Hays. For isotope analyses of water, water samples were acidified to remove carbonates, dried at $60^{\circ} \mathrm{C}$ without washing to avoid loss of soluble organic matter, ground to fine powder, and homogenized. These homogenized residues were chiefly composed of organic carbon and nitrate-N. Historical waterquality records for all of the wells, except for C-24, showed nitrate-N as the primary form of nitrogen in these waters (fig. 2).

Soil samples for organic carbon (OC) and total nitrogen (TN) content and isotopic composition were acidified to dampness with $30 \% \mathrm{HCl}$ to remove carbonates, dried without washing to avoid loss of soluble organic matter, and ground to a homogenous powder. Isotopic analyses were determined using an elemental analyser (EA) coupled through continuous flow with an OPTIMA stable isotope ratio mass spectrometer (GV Micromass, Manchester, UK). Carbon and nitrogen isotopic compositions were reported according to the equation:

$$
\delta^{x} \mathrm{E}(\% \mathrm{o})=\left(\mathrm{R}_{\text {sample }} / \mathrm{R}_{\text {standard }}-1\right) \times 10^{3},
$$

where $\mathrm{E}$ is the given element, $\mathrm{x}$ is the heavy isotope of that element, and $\mathrm{R}={ }^{13} \mathrm{C} /{ }^{12} \mathrm{C}$ or, ${ }^{15} \mathrm{~N} /{ }^{14} \mathrm{~N}$. Internal laboratory reference gases for carbon and nitrogen were calibrated against the respective international standards NBS-19 and atmospheric $\mathrm{N}_{2}$ (Hoefs, 2001). Results were reported in delta notation $(\delta)$ as per mil deviations (\%) from the corresponding international standards of Peedee Belemnite (PDB) and atmospheric $\mathrm{N}_{2}$ (air). Analytical precision for carbon and nitrogen was within $\pm 0.2 \%$.

\section{Nitrogen-15 Natural Abundance Isotope Method}

Natural-abundance nitrogen-isotope analysis is frequently used to assist in determining sources of nitrogen to ground water. Generally, bacteria and plants preferentially use ${ }^{14} \mathrm{~N}$, resulting in an increased $\delta^{15} \mathrm{~N}$ value in the remaining nitrogen. Previous work shows that nitrate- $\mathrm{N}$ in commercial fertilizer sources has $\delta^{15} \mathrm{~N}$ values of -2 to $+2 \%$; soil nitrogen has a range of +5 to $+7 \%$; and animal waste generally has values greater than $+10 \%$ (Heaton, 1986; Herbel and Spalding, 1993; Townsend et al., 1996).

Ground water in Kansas that has received frequent inputs of fertilizer has measurable nitrate- $\mathrm{N}$ generally greater than $2 \mathrm{mg} / \mathrm{L}$, the pristine water value established by the U.S. Geological Survey (Mueller and Helsel, 1996; Townsend and Young, 2000). Anhydrous ammonia is the primary fertilizer used in much of Kansas (KDA, 2006). Because of possible volatilization of anhydrous ammonia by bacterial or chemical processes (Herbel and Spalding, 1993; Korom, 1992), observed $\delta^{15} \mathrm{~N}$ values frequently are in the +2 to $+8 \%$ o range (Townsend and Young, 2000). Other sources such as human-septic waste or animal waste have $\delta^{15} \mathrm{~N}$ values around $+5 \%$ when excreted. Animal waste has a high ammonia component and because of the preferential release of ${ }^{14} \mathrm{~N}$ by

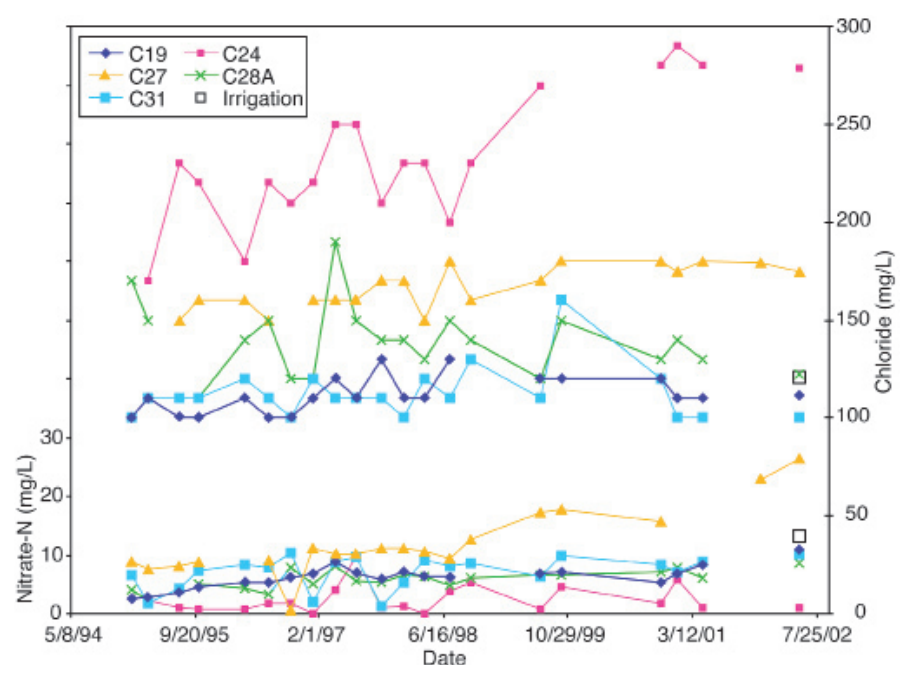

FIGURE 2-Historic nitrate-N and chloride values for wells sampled in study. Most of the wells show an upward trend in nitrate-N. Chloride is highest in well C-24, which had reducing water chemistry and lowest nitrate- $\mathrm{N}$ values. All other wells have chloride within a range of 100 to $175 \mathrm{mg} / \mathrm{L}$ (Appendix A). Data obtained from City of Hays manager (personal communication, 2002). 
the volatilization of ammonia (Kreitler, 1975), the remaining nitrogen becomes enriched in $\delta^{15} \mathrm{~N}$ to a value of $+10 \%$ or more. Generally in Kansas, with animal-waste sources, nitrate- $\mathrm{N}$ values are commonly more than $10 \mathrm{mg} / \mathrm{L}$ and $\delta^{15} \mathrm{~N}$ values are above $+10 \%$ (Townsend et al., 2003).

Volatilization also can occur in soils and rocks with carbonate zones (caliche). These zones act as temporary perching zones for downward-moving water. The carbonates can increase the $\mathrm{pH}$ of water towards 8.5; in this range nitrate- $\mathrm{N}$ can be converted chemically to ammonia gas. The lighter ${ }^{14} \mathrm{~N}$ isotope is preferentially released with the gas. The remaining nitrogen becomes enriched with $\delta^{15} \mathrm{~N}$ of a higher value (Herbel and Spalding, 1993).

Denitrification also can result in an enriched $\delta^{15} \mathrm{~N}$ value by bacterial degradation of nitrate- $\mathrm{N}$ to nitrogen gases that are released to the atmosphere. The preferential utilization of ${ }^{14} \mathrm{~N}$ of the nitrate by the bacteria results in an enriched $\delta^{15} \mathrm{~N}$ in the remaining nitrate. Signs of possible denitrification observed in other areas of Kansas are low nitrate-N values; enriched $\delta^{15} \mathrm{~N}$ values; high levels of bicarbonate, which is a byproduct of the denitrification process (Kendall, 1998); reducing water chemistry with $\mathrm{pH}$ less than 6 ; measurable iron and manganese; and a hydrogen sulfide odor (Townsend and Sleezer, 1995).

\section{Carbon-13 Natural Abundance Isotope Method}

As with the ${ }^{15} \mathrm{~N}$ natural-abundance method, the ${ }^{13} \mathrm{C}$ natural-abundance method reflects the sources of carbon as well as the impacts of biological recycling of the carbon. Trees, shrubs, cool-weather grasses, and crops, including wheat, rye, and oats, are classified as $\mathrm{C}_{3}$ and have a $\delta^{13} \mathrm{C}$ range from -20 to $-32 \%$ and a mean of $-27 \%$. Other plants, such as corn, sorghum, sugar cane, and warmer-weather grasses, are classified as $\mathrm{C}_{4}$ plants and have a $\delta^{13} \mathrm{C}$ range from -10 to $-17 \%$, with an average of $-12 \%$ (Johnson et al., 2007; Ehleringer et al., 2000).

In terrestrial settings most $\delta^{13} \mathrm{C}_{\mathrm{DOC}}$ values in ground water vary from -26 to $-30 \%$, which is similar to the $\delta^{13} \mathrm{C}$ signature of the $\mathrm{C}_{3}$ plants listed above. Where $\mathrm{C}_{4}$ plants are prevalent $\delta^{13} \mathrm{C}_{\mathrm{DOC}}$ values in ground water occur up to $-18 \%$ (Spalding et al., 1978; Wang et al., 1998). In general the $\delta^{13} \mathrm{C}_{\mathrm{DOC}}$ in most ground waters reflects the average carbon isotope values of the local decomposing plant material (Wang et al., 1998; Deines, 1980).

Carbon-13 is also a good indicator of animal diet. Fecal material from pigs fed either a $100 \% \mathrm{C}_{3}$ (soybean [-24.0\%o], barley [-25.3\%o], and alfalfa [-26.0\%o]; fecal matter [-25.7\%o]) or $\mathrm{C}_{4}$ (corn [-11.3\%o]; fecal matter [-12.8\%o]) diet reflected the $\delta^{13} \mathrm{C}$ values mentioned previously (Hare et al., 1991). Use of carbon-13 values can help to determine potential plant sources for DOC in soils and in ground water. Similarities or differences in the $\delta^{13} \mathrm{C}$ values between soils and ground water suggest the potential for determining if soils are a major contributor to observed $\delta^{13} \mathrm{C}_{\mathrm{DOC}}$ in ground water.

\section{Statistical Analyses}

Nonparametric methods and the SPLUS ${ }^{\circledast}$ ver. 7 statistical package (Insightful Corporation, 2005) were used for statistical analysis of water samples from this study in addition to the chloride (251 samples) and nitrate ( 254 samples) data obtained from the City of Hays (City of Hays manager, personal communication, 2002). Nitrate and chloride data were found to be non-normal in distribution based on the Shapiro-Wilks test.

The Mann-Kendall test for trend (Helsel and Hirsch, 1995) was used to evaluate the nitrate- $\mathrm{N}$ and chloride trends observed in some of the wells (fig. 2). The test uses tau ( $\tau$ ) to evaluate the monotonic correlation between concentration and time. Tau is the non-parametric equivalent of the parametric statistical correlation coefficient (r). If the concentration of a parameter increases with time, then $\tau$ will have a positive value and the calculated probability level, $p$, is compared to the significance level, $\alpha$, assigned to the test. Because of the geologic and spatial variability throughout the area, $\alpha$ was set at 0.10 (Davis, 1986).

If the $p$-value ( $p$ ) for a given test is less than $\alpha=0.10$, the test is considered significant and the null hypothesis of

$$
\mathrm{H}_{0}=\text { no trend observed }
$$

is rejected.

\section{Results and Discussion}

\section{Water Chemistry}

Water chemistry in the Hays area is a predominantly calcium-mixed-anion-type water. The anions of bicarbonate, sulfate, and chloride are the main contributors to the specific conductance (fig. 3; Appendix B). Nitrate-N concentration near or above the drinking-water limit of $10 \mathrm{mg} / \mathrm{L}$ (U.S. EPA, 2003) occurred in several of the city wells (fig. 2, Appendix B).

Figure 3 portrays the correlation of anions contributing to specific conductance. This relationship in water chemistry is often observed in semi-arid environments with high evapotranspiration (Townsend and Macko, 2005; Hem, 1985).
Nitrate-N also follows this trend if well C-24 is not included in the analysis (table 2), suggesting that evapoconcentration of water with fertilizer may be a source of the high nitrate. However, $\delta^{15} \mathrm{~N}$ values for the water samples do not support this conclusion (fig. 4). Well C-24 has higher specific conductance, chloride, and bicarbonate values and a much lower nitrate- $\mathrm{N}$ concentration than the other wells. These values are indicative of reducing water chemistry. Because of the very low nitrate-N value (Appendix B), well C-24 was not included in fig. 3.

Figure 2 illustrates the range of nitrate- $\mathrm{N}$ and chloride values from 1995 to 2002 (City of Hays manager, personal communication, 2002). Overall, the nitrate- $\mathrm{N}$ concentration 


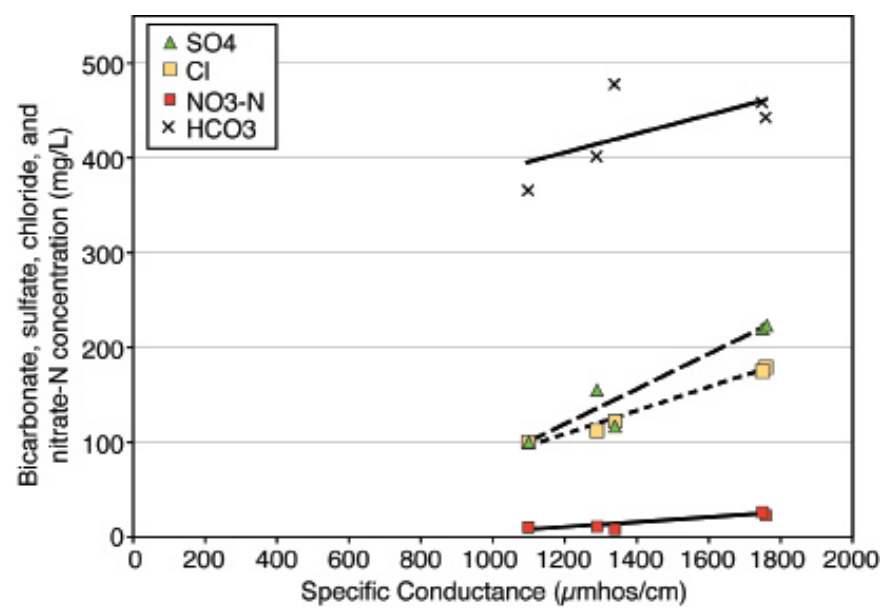

FIGURE 3 - Contribution of bicarbonate, sulfate, and chloride anions and nitrate- $\mathrm{N}$ concentration to specific conductance values. Increasing values suggest impacts of evapoconcentration on ground water in the area (table 2). Wells C-27, C-19, C-28A, and $\mathrm{C}-31$ are plotted on figure. Well C-24 values are not plotted in fig. 3.

shows an increasing trend, particularly in well C-27, which is surrounded on the west and south by farmed land (fig. 1). In well C-24 chloride concentrations are much higher and nitrate- $\mathrm{N}$ values are generally lower than in the other wells. This well is not routinely used and has a reducing water quality (Appendix A). The $\delta^{15} \mathrm{~N}$ value for this well (discussed in next section) indicates that denitrification may have occurred.

Table 3 shows the results of the Mann-Kendall test for increasing or decreasing trend of nitrate- $\mathrm{N}$ and chloride values in ground-water samples from all city wells sampled in the Hays area from 1995 to 2000, plus the results from this study. The nitrate- $\mathrm{N}$ and chloride values from this study were included for wells C-19, C-27, C-31, C-24, and C-28A. All wells sampled in this study, except for well C-24, showed a statistically significant increasing trend (shown by a positive $\tau$ value) for nitrate-N (table 3 ). These results, plus the significance levels (shown by the $p$ value) for three of the other city wells (C-32, YE-1, and YE-2), suggest that nitrate-N is increasing throughout the area, although the rate of nitrate concentration increase is not the same for all of the wells.

Three of the wells from this study (C-19, C-24, and $\mathrm{C}-27)$ plus two other city wells (C-21 and C-30) showed a statistically significant increasing trend for chloride (table 3 ). Well C-24 showed a significant chloride increase but not for nitrate-N. These results are related to the observed reducing water quality at well C-24.

\section{Nitrogen Isotope Evaluation of City of Hays Well Field}

The nitrate-N observed in the wells most likely comes from several sources. As shown in fig. 1, the Irrigation Well is on the south side of the river and the other wells are located to the north. At the time of this study (2002) all of the sampled wells except C-24 and C-28A had nitrate-N concentrations

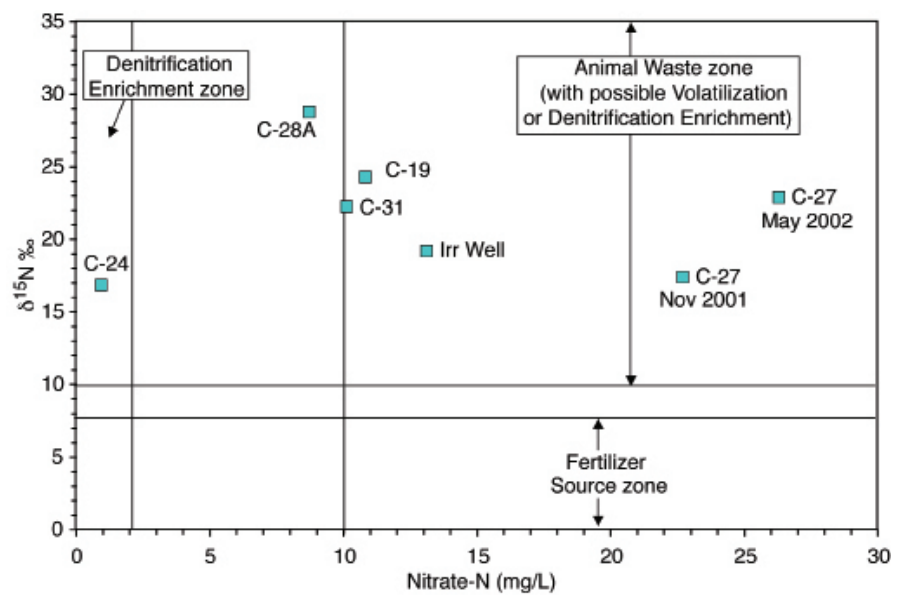

FIGURE 4-Range of nitrate- $\mathrm{N}$ and $\delta^{15} \mathrm{~N}$ values observed in this study. The $\delta^{15} \mathrm{~N}$ values are all greater than $+10 \%$, which is the lower limit of the animal waste and probable denitrification and/or volatilization enrichment zone on the graph. The line at $2 \mathrm{mg} / \mathrm{L}$ nitrate- $\mathrm{N}$ is the background level for pristine water (Mueller and Helsel, 1996). The line at $10 \mathrm{mg} / \mathrm{L}$ is the U.S. EPA drinking-water limit for nitrate-N (U.S. EPA, 2003).

TABLE 2 - Trend-line $\mathrm{R}^{2}$ values for anion and nitrate-N plot with specific conductance in fig. 3 .

\begin{tabular}{|c|c|c|}
\hline \multirow[b]{2}{*}{ Trend line } & \multicolumn{2}{|l|}{ Without Well C-24 (5 samples) } \\
\hline & Calculated trend line & $\mathbf{R}^{2}$ \\
\hline Nitrate-N & $y=0.0256 x-21.294$ & 0.854 \\
\hline Sulfate & $y=0.1851 x-105$ & 0.913 \\
\hline Chloride & $y=0.1234 x-42.317$ & 0.985 \\
\hline \multirow[t]{2}{*}{ Bicarbonate } & $y=0.099 x+285.06$ & 0.415 \\
\hline & With Well C-24 (6 samples) & \\
\hline Trend line & Calculated trend line & $\mathbf{R}^{2}$ \\
\hline Nitrate-N & $y=0.0024 x+15.233$ & 0.012 \\
\hline Sulfate & $y=0.2121 x-145.68$ & 0.946 \\
\hline Chloride & $y=0.1764 x-107.58$ & 0.936 \\
\hline Bicarbonate & $y=0.117 x+260.68$ & 0.677 \\
\hline
\end{tabular}

measured above the drinking-water limit of $10 \mathrm{mg} / \mathrm{L}$ ( fig. 2; Appendix A). Measured $\delta^{15} \mathrm{~N}$ values are all greater than $+10 \%$ and appear to be derived from animal waste, possibly affected by denitrification or volatilization enrichments (fig. 4). The relationship between high nitrate- $\mathrm{N}$ concentrations and enriched $\delta^{15} \mathrm{~N}$ values has been observed in other studies in Kansas and other states and is usually related to an animalwaste source (Townsend et al., 2001; Fogg et al., 1998). Possible sources include animal waste from feedlots, pastures, manure used as fertilizer in the past, or leaking septic or wastewater-treatment systems. Movement of nitrate-rich water from the surface to ground water could occur through macropore flow (described in next section) or possibly through 
TABLE 3-Kendall test for trend results for City of Hays wells (1995-2002). Wells in the study and statistically significant $p$ values are shown in bold.

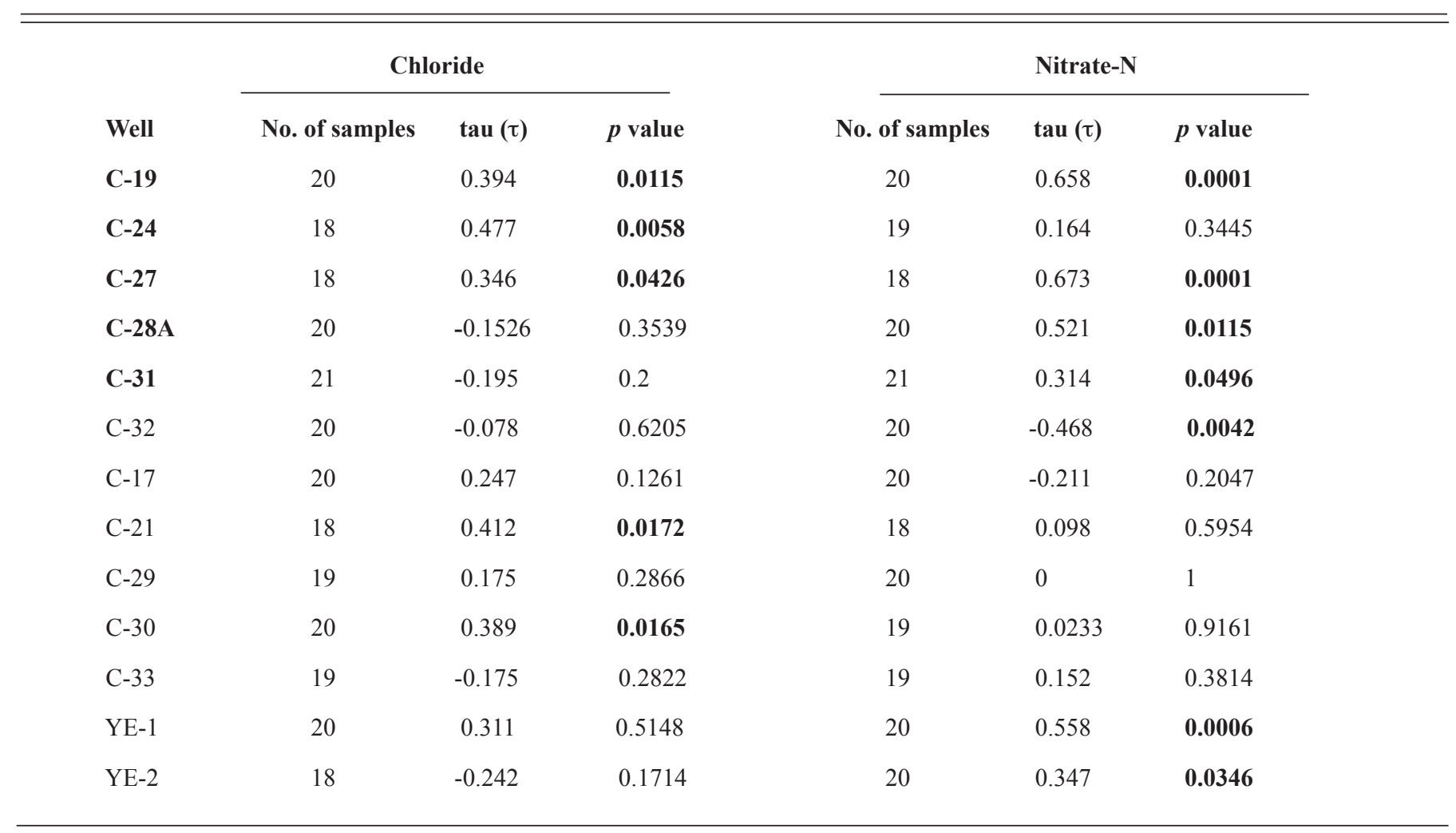

poor well construction. No well survey of old or abandoned wells was done during this study, but work in other parts of Kansas indicates that poor well construction may permit movement of contaminated water to ground water (Townsend et al., 2001).

Well C-24 has a higher specific conductance reading and higher chloride and sulfate concentrations than the other wells, suggesting that this well has reducing water chemistry (Appendix A). This well also has a very low nitrate- $\mathrm{N}$ value, an enriched $\delta^{15} \mathrm{~N}$ value, and a higher bicarbonate value, which suggests that potential denitrification reactions have occurred in the ground water resulting in the observed enriched $\delta^{15} \mathrm{~N}$ (Herbel and Spalding, 1993).

\section{Nitrogen Isotope Evaluation of Soil Cores}

Soil cores collected near the M-319 monitoring wells and at the agricultural irrigation site have $\delta^{15} \mathrm{~N}$ values that show an overall increase with depth, while the other three cores show either little change or decreased values (fig. 5b; Appendix B). Percent total nitrogen values for all of the soil cores decrease with depth. The decreasing percent total nitrogen values and increased $\delta^{15} \mathrm{~N}$ values are similar to findings from other researchers (figs. 5a, 5b; Appendix B; Broadbent et al., 1980; Karamanos et al., 1981; Shearer et al., 1978; Rennie et al., 1976). The decreasing percent total nitrogen at all sites and the increased $\delta^{15} \mathrm{~N}$ values at depth for several of the cores suggests that microbial action is impacting the nitrogen content of the soil and contributing to the observed increasing $\delta^{15} \mathrm{~N}$ values at some sites.

Although organic nitrogen is probably being utilized by microbes, the organic nitrogen likely is not being converted into a form that is moveable by soil water. A C:N $>15$ generally means that nitrogen is not available for plant use and is mineralized (Ihori et al., 1995). In the study area a mean $\mathrm{C}: \mathrm{N}$ of 16.7 suggests that the organic nitrogen portion of the soil is not available for use by plants and may not be available as the labile phase in soil water (Appendix B).

Nitrate- $\mathrm{N}$ and ammonium-N concentrations from the cores vary with depth but not as much as the percent total nitrogen (figs. 5a, 5c, 5d). Calculated range, mean, and median nitrate-N concentrations in $\mathrm{mg} / \mathrm{L}$ for the Detroit and Roxbury soils are shown in table 4. Except for those found at the irrigated site, the nitrate- $\mathrm{N}$ values are generally less than the quantity observed in the measured ground-water samples. The mean $\delta^{15} \mathrm{~N}$ value of all soil cores is $+10.7 \%$, which is also considerably below the value observed in the ground water (Appendices A and B).

Denitrification or volatilization processes in the soil zone may have contributed to the enrichment of the $\delta^{15} \mathrm{~N}$ values with depth, but it is unlikely that the observed nitrate- $\mathrm{N}$ in the unsaturated zone is the primary source of nitrate- $\mathrm{N}$ in the ground water because both the nitrate- $\mathrm{N}$ and $\delta^{15} \mathrm{~N}$ values are much lower than those observed in the ground water (Appendices A and B). 

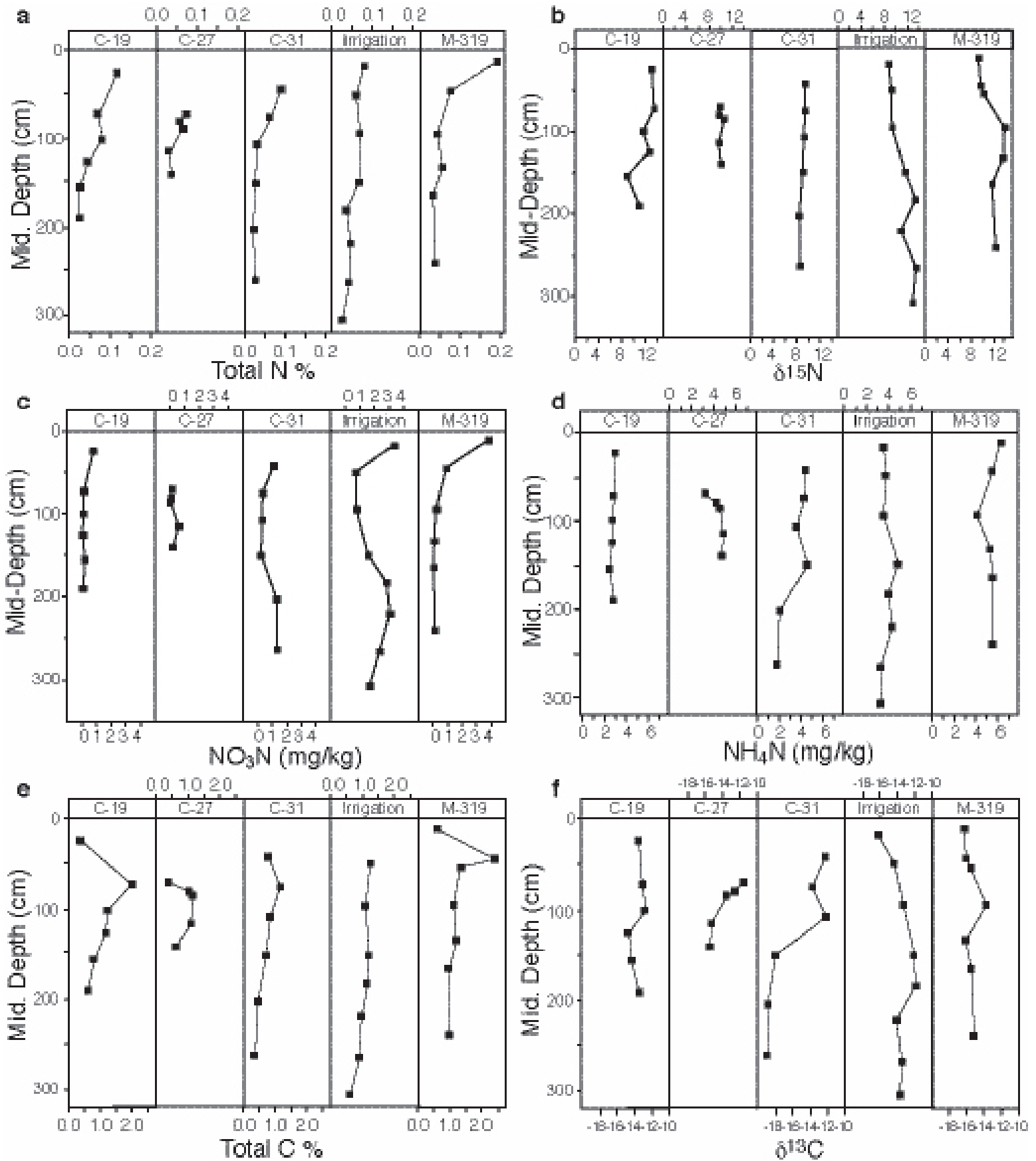

FIGURE 5-Soil chemical properties of percent total nitrogen $(5 \mathrm{a}), \delta^{15} \mathrm{~N}(5 \mathrm{~b})$, nitrate-N (5c), ammonium-N (5d), percent total carbon (5e), and $\delta^{13} \mathrm{C}(5 \mathrm{f})$ for the five sampling sites.

\section{Carbon Isotope Evaluation of Soil and Ground Water}

The $\delta^{13} \mathrm{C}$ values in the soil cores reflect the occurrence of $\mathrm{C}_{4}$ plants as the primary source of carbon in the soil profile (Appendix B). Although the percent total organic carbon decreases with depth (as did the percent total nitrogen discussed previously), suggesting some bacterial degradation, the $\delta^{13} \mathrm{C}$ values do not generally show enrichment with depth except at the Irrigated Well area (figs. 1, 5e, 5f).

$\delta^{13} \mathrm{C}$ values and $\delta^{15} \mathrm{~N}$ values for the sampled cores and ground water are compared in fig. 6 . The soil cores were collected to approximately $3-\mathrm{m}$ depth, whereas the water table is at $7-8 \mathrm{~m}$.

The $\delta^{13} \mathrm{C}$ values are enriched for the soils and depleted for the ground water indicating the possibility of different sources for the dissolved organic carbon. As discussed previously, the estimated soil nitrate-N values for the soils converted to $\mathrm{mg} / \mathrm{L}$ (table 4 ) show an overall mean of 5.7 $\mathrm{mg} / \mathrm{L}$. The maximum calculated values for the area are a 28.1 $\mathrm{mg} / \mathrm{L}$ surface sample taken near the M-319 monitoring wells and a $24.4 \mathrm{mg} / \mathrm{L}$ sample from the Irrigated Well area (fig. 1; table 4; Appendix B), with a decrease of nitrate-N and percent total nitrogen with depth at all sites. This suggests that 
TABLE 4-Comparison of calculated nitrate-N values from soils with observed ground-water nitrate-N values.

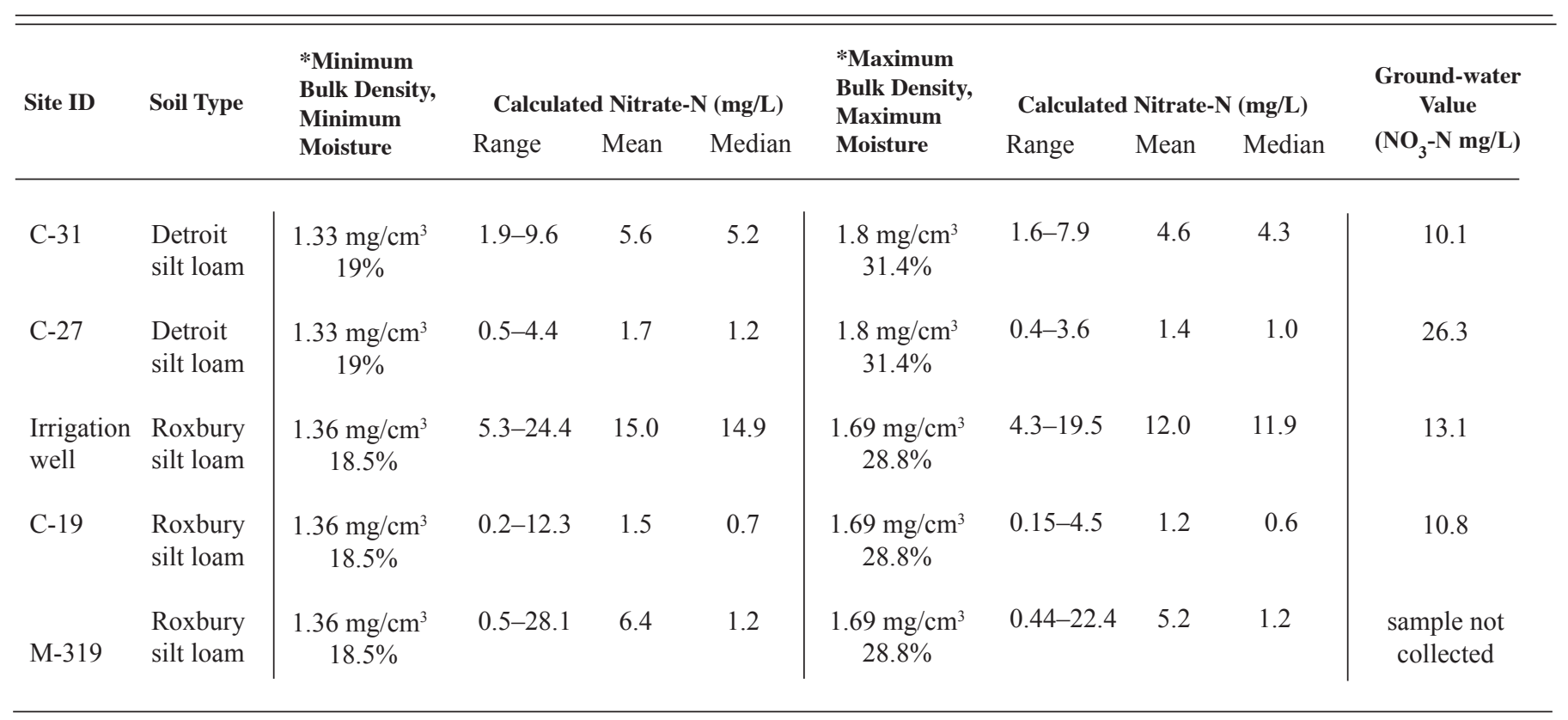

*Data from NRCS national soil survey characterization data (http://ssldata.nrcs.usda.gov/)

nitrate- $\mathrm{N}$ in the soil profile is not the major source of nitrogen to ground water.

Sources of nitrogen and carbon to ground water enriched in $\delta^{15} \mathrm{~N}$ and depleted in $\delta^{13} \mathrm{C}$ may be related to waste from animals utilizing $\mathrm{C}_{3}$ plants as a food source or from previous land use, such as farming of $\mathrm{C}_{3}$ plants. The soils collected for this study are enriched in $\delta^{13} \mathrm{C}$ and depleted in $\delta^{15} \mathrm{~N}$, which is expected with current $\mathrm{C}_{4}$ plants (grasses and crops) and microbial utilization of nitrogen. However, if soil organic carbon is the primary source of carbon to ground water, the $\delta^{13} \mathrm{C}$ values would be expected to be more similar in value.

Carbon isotopes in the soils represent current $\mathrm{C}_{4}$ plants, typical of grasses near the wells in the city areas and the sorghum in the irrigated field and fall in a higher range of values (-10 to $-19 \%)$. The $\delta^{13} \mathrm{C}$ of organic carbon in groundwater samples may represent $\mathrm{C}_{3}$ plant sources, such as wheat, trees, and shrubs, or perhaps human or animal waste (-22 to -30\%o) (Gearing et al., 1991; Boutton, 1996; Mortatti et al., 2004). At this point, the ${ }^{13} \mathrm{C}$ data are inconclusive as to the exact sources of the carbon. However, the data do suggest two separate sources for the carbon in the soil and ground water.

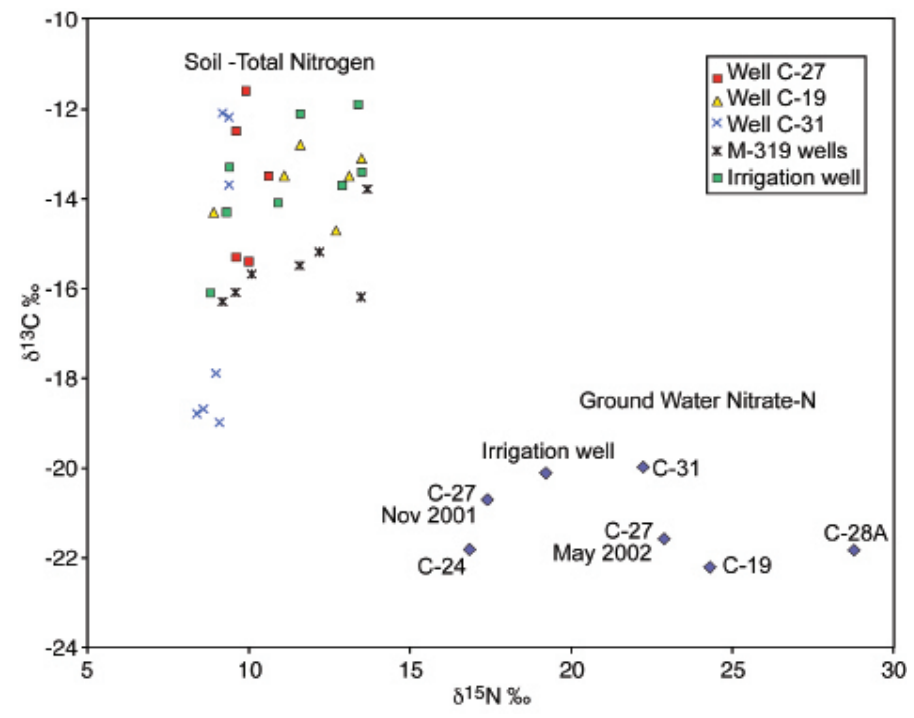

FIGURE $6-\delta^{13} \mathrm{C}$ and $\delta^{15} \mathrm{~N}$ values for both soils and ground water in the study area. Graph indicates separation of carbon and nitrogen sources between soil and ground-water values.

\section{Conclusions}

The use of the natural abundances of ${ }^{15} \mathrm{~N}$ and ${ }^{13} \mathrm{C}$ to determine sources of nitrate- $\mathrm{N}$ contamination in the Hays, Kansas, well field indicates the possibility that human and/or animal waste is a source of contamination to the ground water in this location. Well C-27 is nearest to the closed sewagetreatment plant and is near farmland that may have been fertilized with manure in the past. This well has the highest nitrate- $\mathrm{N}$ and $\delta^{15} \mathrm{~N}$ values. Wells $\mathrm{C}-28 \mathrm{~A}, \mathrm{C}-19$, and $\mathrm{C}-31$ have lower nitrate- $\mathrm{N}$ values, but their $\delta^{15} \mathrm{~N}$ values are similar to the enriched values measured at C-27.
Lower nitrate-N values may indicate possible denitrification reduction of the nitrate-N concentration and/ or dilution by mixing with other lower nitrate-N water. Occurrence of higher nitrate- $\mathrm{N}$ and enriched $\delta^{15} \mathrm{~N}$ values in the ground water suggests that possible macropore flow in the unsaturated zone or poor well construction may provide avenues for flow of contaminated water to ground water somewhere in the city area. The field descriptions of the soils indicate the presence of continuous tubular pores and fine roots throughout the core. These pores and root channels may 
permit some macropore flow without the retention time needed to decrease the nitrate-N concentrations. Further study is needed to verify this. Also, a survey of wells in the city would be helpful to determine if there are possible avenues for flow due to poor well construction.

Soil chemical profiles and water chemistry indicate that denitrification and volatilization enrichment may be occurring both in the unsaturated zone and in ground water. Presence of abundant calcium carbonate in the soils could permit the changes in the $\mathrm{pH}$ of the water necessary for volatilization to occur. The $\delta^{15} \mathrm{~N}$ values generally increase with depth in two of the cores. The soils contain sufficient nitrogen and carbon to permit denitrification to occur in the profile with the resulting enriched $\delta^{15} \mathrm{~N}$ values. However, both the nitrate- $\mathrm{N}$ and $\delta^{15} \mathrm{~N}$ values are much lower than in the ground-water samples, suggesting that the soils are not a primary source of nitrogen for the ground water.

The $\delta^{13} \mathrm{C}$ values are enriched in the soils indicating that $\mathrm{C}_{4}$ plants, such as warm-weather grasses, and other plants, such as sorghum, may be a primary source of the carbon. The values in the ground water are in the range for $\mathrm{C}_{3}$ plants and particularly the range common for animal and human waste, as observed in other studies.

Testing both soil and ground-water samples for ${ }^{13} \mathrm{C}$ and ${ }^{15} \mathrm{~N}$ values and nitrogen and carbon contents provides a wider context for evaluation of nitrogen sources. Land use, plant types and classification as $\mathrm{C}_{3}$ or $\mathrm{C}_{4}$ carbon sources, location of potential human- and animal-waste sources, and soil descriptions in terms of caliche and carbonate zones all provide essential information to help define nitrate sources. The results from this study are encouraging for the use of both ${ }^{13} \mathrm{C}$ and ${ }^{15} \mathrm{~N}$ for source identification of nitrate- $\mathrm{N}$ in ground water.

Acknowledgments - The authors wish to thank personnel from the City of Hays for their assistance in sampling wells, the soil scientists from the northwest Kansas NRCS for their help in collecting and describing soil cores in the area, and the staff at the Kansas Geological Survey for editing, graphic design, and review of this paper.

\section{References}

Boutton, T. W., 1996, Stable carbon isotope ratio of soil organic matter and their use as indicators of vegetation and climate change; in, Mass Spectrometry of Soils, T.W. Boutton and S. Yamasaki, eds.: New York, Academic Press, p. 7-82.

Broadbent, F. E., Rauschkolb, R. S., Lewis, K. A., and Chang, G. Y., 1980, Spatial variability of nitrogen-15 and total nitrogen in some virgin and cultivated soils: Soil Science Society of America Journal, v. 44, p. 403-432.

Davis, J. C., 1986, Statistics and data analysis in geology: John Wiley and Sons, Inc., 646 p.

Deines, P., 1980, The isotopic composition of reduced organic carbon; in, Handbook of Environmental Isotope Geochemistry, 1, The Terrestrial Environment, P. Fritz and J. C. Fontes, eds.: Amsterdam, Elsevier, p. 329-406.

DWR and KGS (Division of Water Resources, Kansas Department of Agriculture, and Kansas Geological Survey), 2005, WIMAS (Water Information Management and Analysis System), Version 5 for the web: Kansas Geological Survey, http://hercules.kgs.ku.edu/geohydro/ wimas/index.cfm (verified March 2008).

Ehleringer, J. R., Buchmann, N., and Flanagan, L. B., 2000, Carbon isotope ratios in belowground carbon cycle processes: Ecological Applications, v. 10, no. 2, p. 412-422.

Fogg, G.E., Rolston, D. E., Decker, D. L., Louie, D. T., and Grismer, M. E., 1998, Spatial variation in nitrogen isotope values beneath nitrate contamination sources: Ground Water, v. 36, no. 3, p. 418-426.

Gearing, P. J., Gearing, J. N., Maughan, J. T., and Oviatt, C. A., 1991, Isotopic distribution of carbon from sewage sludge and eutrophication in the sediments and food web of estuarine ecosystems: Environmental Science and Technology, v. 25, p. 295-301.
Hare, P. E., Fogel, M. L., Stafford, T. W., Jr., Mitchell, A. D., and Hoering, T. C., 1991, The isotopic composition of carbon and nitrogen in individual amino acids isolated from modern and fossil proteins: Journal of Archaeological Science, v. 18, p. 277-292.

Hathaway, L. R., 1990, Nitrate UV-spectrophotometric screening method for the Technicon Autoanalyzer II System: Kansas Geological Survey, Open-file Report 90-49, 4 p.

Hathaway, L. R., Carr, B. L., Galle, O., Magnuson, L. M., Waugh, T. C., and Dickey, H. P., 1977, Chemical quality of irrigation waters in Hamilton, Kearny, Finney and northern Gray counties: Kansas Geological Survey, Chemical Quality Series 4, 33 p.

Heaton, T. H. E., 1986, Isotopic studies of nitrogen pollution in the hydrosphere and atmosphere - a review: Chemical Geology, v. 59, p. 87-102.

Helsel, D. R., and Hirsch, R. M., 1995, Statistical methods in water resources, Studies in Environmental Science 49: New York, Elsevier, 529 p.; also available at http://pubs. usgs.gov/twri/twri4a3/\#pdf, (verified August 2007).

Hem, J. D., 1985, Study and interpretation of the chemical characteristics of natural water, $3 \mathrm{~d}$ ed.: U.S. Geological Survey, Water-Supply Paper 2254, 263 p.

Herbel, M. J., and Spalding, R. F., 1993, Vadose zone fertilizer-derived nitrate and $\delta^{15} \mathrm{~N}$ extracts: Ground Water, v. 31, no. 3, p. 316-322.

Hoefs, J., 2001, Stable isotope geochemistry, 4th ed.: Springer, $201 \mathrm{p}$.

Ihori, T., Burke, I. C., and Hook, P. B., 1995, Nitrogen mineralization in native cultivated and abandoned fields in shortgrass steppe: Plant and Soil, v. 171, p. 203-208. 
Insightful Corporation, 2005, SPLUS ${ }^{\circledast}$ Professional Developer Version 7.0.2 for Microsoft Windows: Seattle, Insightful Corporation.

Johnson, W. C., Willey, K. L., Macpherson, G. L., 2007, Carbon isotope variation in modern soils of the tallgrass prairie-Analogues for the interpretation of isotopic records derived from paleosols: Quaternary International, v. $162-163$, p. 3-20.

KDA (Kansas Department of Agriculture), 2006, Pesticide and fertilizer program fertilizer tonnage report: Grade 1-5: Kansas Department of Agriculture, www.ksda.gov/ pesticides_fertilizer (verified December 2007).

KSU (Kansas State University), 2006, Research soil testing methods, KSU Soil Testing Laboratory, http://www.oznet. $\mathrm{ksu}$. edu/dp_agrn/SoilTesting/r_soil_testing.htm (verified August 2006).

Karamanos, R. E., Voroney, R. P., and Rennie, D. A., 1981, Variation in natural N-15 abundance of central Saskatchewan soils: Soil Science Society of America Journal, v. 45, p. 826-828.

Kendall, C., 1998, Tracing nitrogen sources and cycling in catchments; in, Isotope Tracers in Catchment Hydrology, C. Kendall and J. J. McDonnell, eds.: Amsterdam, Elsevier, p. 519-576.

Korom, S. F., 1992, Natural denitrification in the saturated zone - a review: Water Resources Research, v. 28, p. $1,657-1,668$.

Kreitler, C. W., 1975, Determining the source of nitrate in ground water by nitrogen isotope studies: University of Texas (Austin), Bureau of Economic Geology, Report of Investigations, no. $83,57 \mathrm{p}$.

LECO Corporation, 1995, Carbon, nitrogen, and sulfur testing in soil/plant tissue: St. Joseph, Michigan, LECO Corporation, CNS 2000 instrument method, Form No. 203-821-002.

LECO Corporation, 2000, Total/organic carbon and nitrogen in soils: St. Joseph, Michigan, LECO Corporation, CNS 2000 instrument method, Form No. 203-821-165.

Mortatti, J., Evangelista, R. A. O., Bendassolli, J. A., Trivelin, P. C. O., Milde, L. C. E., and Santana, A. G. B., 2004, Characterization of domestic sewage in riverine system using carbon-13 and nitrogen-15 tracers: Revista de Ciência \& Tecnologia, v. 11, no. 2, p. 37-44.

Mueller, D. K., and Helsel, D. R., 1996, Nutrients in the nation's waters - too much of a good thing?: U.S. Geological Survey, Circular 1136, 24 p., http://water.usgs. gov/nawqa/circ-1136/circ-1136main.html (verified June 2005).

Neuhauser, K. R., and Pool, J. C., 1988, Geologic map, Ellis County, Kansas: Kansas Geological Survey, Map M-19, scale.1:53,870, http://www.kgs.ku.edu/General/Geology/ County/def/ellis.html (verified June 2005).

Pope, L. M., Bruce, B. W., and Hansen, C. V., 2001, Groundwater quality in Quaternary deposits of the central High Plains aquifer, south-central Kansas, 1999: U.S. Geological Survey, Water Resources Investigations Report 00-4259, 44 p., http://co.water.usgs.gov/nawqa/ hpgw/PUBS.html\#Reports (verified June 2005).
Rennie, D. A., Paul, E. A., and Johns, L. E., 1976, Natural nitrogen-15 abundance of soil and plant samples: Canadian Journal of Soil Science, v. 56, p. 43-50.

Shearer, G., Kohl, D. H., and Chien, S. H., 1978, The nitrogen-15 abundance in a wide variety of soils: Soil Science Society of America Journal, v. 42, p. 899-902.

Sophocleous, M. A., 1998, Perspectives on sustainable development: Kansas Geological Survey, Bulletin 239, p. 9-10.

Spalding, R. F., and Exner, M. E., 1993, Occurrence of nitrate in ground water - a review: Journal of Environmental Quality, v. 22, no. 3, p. 392-402.

Spalding, R. F., Gormly, J. R., and Nash, K G., 1978, Carbon contents and sources in ground waters of the Central Platte Region in Nebraska: Journal of Environmental Quality, v. 7, p. 428-434.

Thornthwaite, C. W., 1948, An approach toward a rational classification of climate: Geographical Review, v. 38, p. 55-94.

Thornwaite, C. W., 1952, Evapotranspiration in the hydrologic cycle; in, Physical Basis of Water Supply and its Principal Uses: U.S. Congress, House of Interior and Insular Affairs Committee, Washington, D. C., p. 25-35.

Townsend, M. A., and Macko, S. A., 2004, Use of nitrogen-15 isotope method in soils and ground water to determine potential nitrogen sources affecting a municipal water supply in Kansas, USA: American Geophysical Union, EOS Transactions, v. 85, no. 47, Fall Meet. Suppl., H41D-0330. http://www.agu.org/meetings/fm04/ waisfm04.html (verified December 2007).

Townsend, M. A., and Macko, S. A., 2005, Evapoconcentration not an indicator of nitrate in Kansas ground water: 15 th V. M. Goldschmidt Conference, May 2005, Moscow, Idaho, Abstracts, p. A605.

Townsend, M. A., and Sleezer, R. O., 1995, Drainage basin scale variation of nitrate- $\mathrm{N}$ concentrations in ground water, Harvey County, Kansas: Geological Society of America, 1995 Abstracts with Programs of NorthCentral Section and South-Central Section, University of Nebraska-Lincoln, p. A-90.

Townsend, M. A., and Young, D. P., 2000, Assessment of nitrate-nitrogen distribution in Kansas ground water, 1990-1998: Natural Resources Research, v. 9, no. 2, p. 125-134.

Townsend, M. A., Macko, S. A., and Young, D. P., 2001, Distribution and sources of nitrate-nitrogen in Kansas ground water; in, Optimizing Nitrogen Management in Food and Energy Production and Environmental Protection: Proceedings of the 2nd International Nitrogen Conference on Science and Policy, The ScientificWorld, v. 1, no. S2, p. 216-222.

Townsend, M. A., Sleezer, R. O., and Macko, S. A., 1996, Effects of agricultural practices and vadose zone stratigraphy on nitrate concentration in ground water in Kansas, USA: Water Science and Technology, v. 33, no. 4-5, p. 219-226.

Townsend, M. A., Young, D. P., and Macko, S. A., 2003, Kansas case study applications of nitrogen-15 natural 
abundance method for identification of nitrate sources:

Journal of Hazardous Substance Research, v. 4, no. 4, 22 p., http://www.engg.ksu.edu/HSRC/JHSR/v4_no4.pdf (verified December 2007).

USDA NRCS (U.S. Department of Agriculture, Natural Resources Conservation Service), 2002, Soil characterization data base: U.S. Department of Agriculture, http://ssldata.nrcs.usda.gov/ (verified August 2007).

USDA NRCS (U.S. Department of Agriculture, Natural Resources Conservation Service), 2006, Web Soil Survey: U.S. Department of Agriculture, http://websoilsurvey.nrcs. usda.gov/app/ (verified August 2007).

USDA SCS (U.S. Department of Agriculture, Soil Conservation Service), 1975, Soil survey of Ellis County, Kansas: U.S. Department of Agriculture, 86 p.
U.S. EPA (U.S. Environmental Protection Agency), 2003, National primary drinking water standards: U.S. Environmental Protection Agency, http://www.epa.gov/ safewater/contaminants/index.html\#inorganic (verified June 2008).

USGS (U.S. Geological Survey), 1983, 7.5-minute series topographic map, Hays South quadrangle, Ellis County, Kansas: U.S. Department of the Interior Geological Survey, scale 1:24,000.

Wang, Y., Huntington, T. G., Osher, L. J., Wassenaar, L. I., Trumbore, S. E., Amundson, R. G., Harden, J. W., McKnight, D. M., Schiff, S. L., Aiken, G. R., Lyons, W. B., Aravena, R. O., and Baron, J. S., 1998, Carbon cycling in terrestrial environments; in, C. Kendall and J. J. McDonnell, Isotope Tracers in Catchment Hydrology: Amsterdam, Elsevier, p. 577-610. 


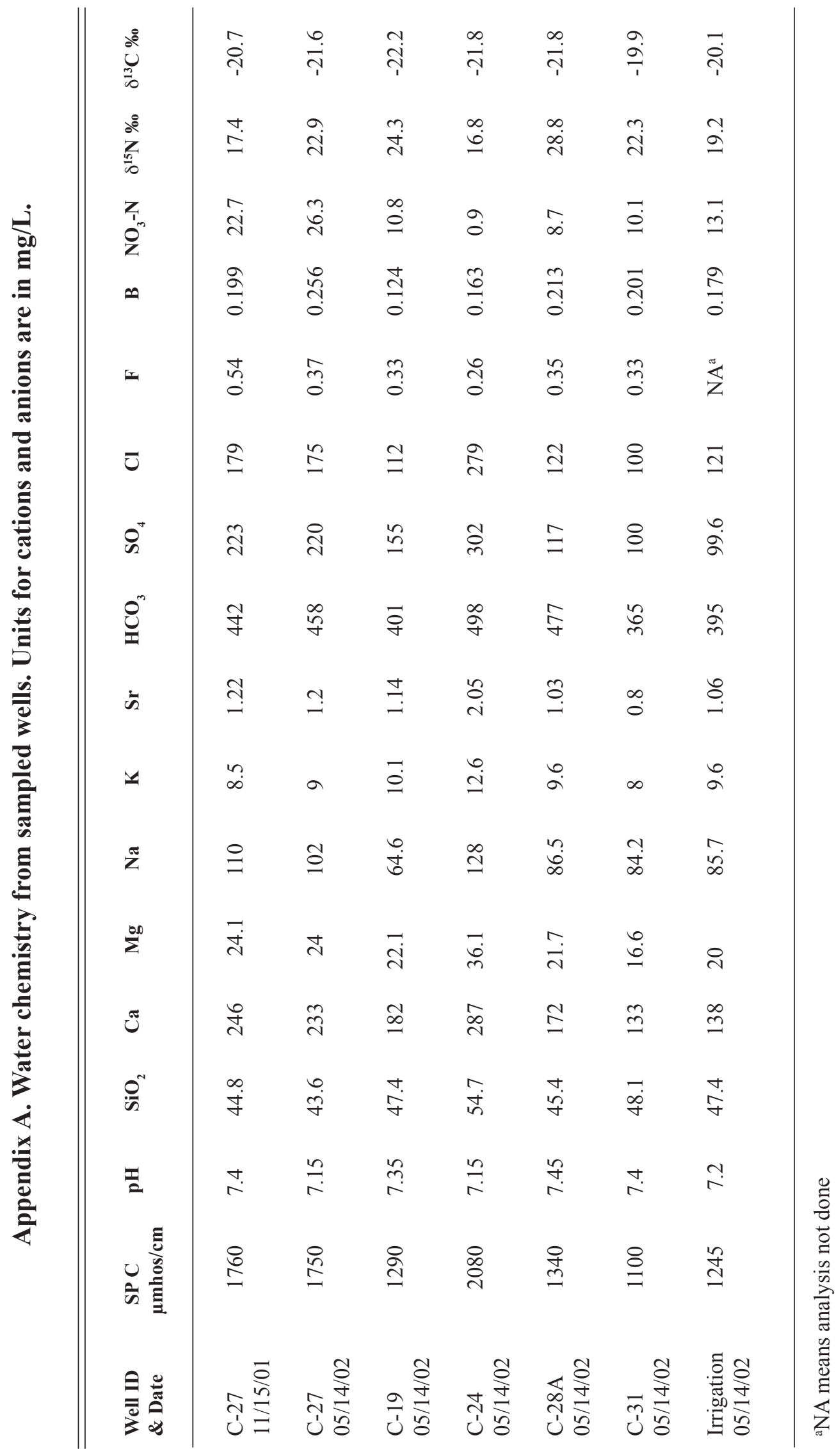




\section{Appendix B. Soils chemical and isotopic data.}

\begin{tabular}{|c|c|c|c|c|c|c|c|c|c|}
\hline Well ID & $\begin{array}{l}\text { Mid-depth } \\
\text { (cm) }\end{array}$ & $\begin{array}{l}\mathrm{NO}_{3}-\mathrm{N} \\
\mathrm{mg} / \mathrm{kg}\end{array}$ & $\begin{array}{l}\mathrm{NH}_{4}-\mathrm{N} \\
\mathrm{mg} / \mathrm{kg}\end{array}$ & Total Na \% & $\begin{array}{c}\delta^{15} \mathbf{N} \\
\text { (Total soil } \\
\mathbf{N}) \\
\%\end{array}$ & $\begin{array}{c}\delta^{13} \mathrm{C} \\
\% 0\end{array}$ & Total C a \% & $\mathrm{CaCO}_{3}{ }^{\mathrm{a}} \%$ & C:N \\
\hline Irr & 18.8 & 3.32 & 3.64 & 0.082 & 8.8 & -16.1 & 1.25 & & 15.3 \\
\hline Irr & 50.0 & 0.72 & 3.85 & 0.063 & 9.3 & -14.3 & 1.11 & & 17.5 \\
\hline Irr & 95.0 & 0.77 & 3.64 & 0.073 & 9.4 & -13.3 & 1.22 & & 16.7 \\
\hline Irr & 150.0 & 1.57 & 4.92 & 0.071 & 11.6 & -12.1 & 1.14 & 2.59 & 16.1 \\
\hline Irr & 182.5 & 2.82 & 4.05 & 0.040 & 13.4 & -11.9 & 0.975 & 4.18 & 24.5 \\
\hline Irr & 220.0 & 3.07 & 4.46 & 0.050 & 10.9 & -14.1 & 0.924 & 3.40 & 18.6 \\
\hline Irr & 265.0 & 2.37 & 3.39 & 0.048 & 13.5 & -13.4 & 0.642 & 1.43 & 13.3 \\
\hline Irr & 307.5 & 1.67 & 3.64 & 0.028 & 12.9 & -13.7 & 0.82 & 3.74 & 28.9 \\
\hline C-31 & 42.5 & 1.12 & 4.46 & 0.094 & 9.4 & -12.2 & 1.2 & & 12.8 \\
\hline C-31 & 75.0 & 0.38 & 4.36 & 0.065 & 9.4 & -13.7 & 0.848 & 3.32 & 13.1 \\
\hline C-31 & 107.5 & 0.33 & 3.64 & 0.034 & 9.2 & -12.1 & 0.72 & 2.03 & 21.2 \\
\hline $\mathrm{C}-31$ & 150.0 & 0.28 & 4.61 & 0.032 & 9.0 & -17.9 & 0.546 & 1.24 & 16.9 \\
\hline C-31 & 202.5 & 1.32 & 2.16 & 0.027 & 8.4 & -18.8 & 0.383 & & 14.4 \\
\hline C-31 & 262.5 & 1.37 & 2.01 & 0.030 & 8.6 & -18.7 & 0.384 & & 12.8 \\
\hline C-19 & 25.0 & 0.77 & 2.98 & 0.119 & 13.1 & -13.5 & 2.02 & & 17.0 \\
\hline C-19 & 72.5 & 0.13 & 2.98 & 0.070 & 13.5 & -13.1 & 1.28 & & 18.4 \\
\hline C-19 & 100.0 & 0.08 & 2.83 & 0.082 & 11.6 & -12.8 & 1.19 & 3.39 & 14.6 \\
\hline C-19 & 125.0 & 0.03 & 2.83 & 0.043 & 12.7 & -14.7 & 0.86 & 1.71 & 19.8 \\
\hline C-19 & 155.0 & 0.18 & 2.57 & 0.029 & 8.9 & -14.3 & 0.692 & & 24.2 \\
\hline C-19 & 190.0 & 0.08 & 2.93 & 0.027 & 11.1 & -13.5 & 0.413 & & 15.5 \\
\hline $\mathrm{C}-27$ & 70.0 & 0.18 & 3.34 & 0.070 & 9.9 & -11.6 & 1.06 & 2.86 & 15.1 \\
\hline $\mathrm{C}-27$ & 80.0 & 0.08 & 4.36 & 0.056 & 9.6 & -12.5 & 1.15 & 3.16 & 20.4 \\
\hline C-27 & 85.0 & 0.08 & 4.61 & 0.064 & 10.6 & -13.5 & 1.13 & 2.70 & 17.8 \\
\hline C-27 & 115.0 & 0.63 & 5.02 & 0.030 & 9.6 & -15.3 & 0.654 & & 21.5 \\
\hline C-27 & 140.0 & 0.28 & 4.92 & 0.038 & 10.0 & -15.4 & 0.63 & & 16.8 \\
\hline M-319 & 12.5 & 3.8193 & 6.35 & 0.194 & 9.2 & -16.3 & 2.3 & & 11.9 \\
\hline M-319 & 45.0 & 0.9245 & 5.53 & 0.077 & 9.6 & -16.1 & 1.6 & & 20.8 \\
\hline M-319 & 95.0 & 0.2258 & 4.25 & 0.050 & 13.7 & -13.8 & 0.47 & 4.23 & 9.5 \\
\hline M-319 & 132.5 & 0.126 & 5.33 & 0.064 & 13.5 & -16.2 & 0.45 & 3.67 & 7.1 \\
\hline M-319 & 165.0 & 0.0761 & 5.63 & 0.042 & 11.6 & -15.5 & 0.66 & & 15.9 \\
\hline M-319 & 240.0 & 0.1759 & 5.63 & 0.045 & 12.2 & -15.2 & 0.48 & & 10.7 \\
\hline
\end{tabular}

${ }^{\text {a }}$ Conversion of percent to ppm: ppm/10,000 $=\%(\mathrm{w} / \mathrm{w})$ 